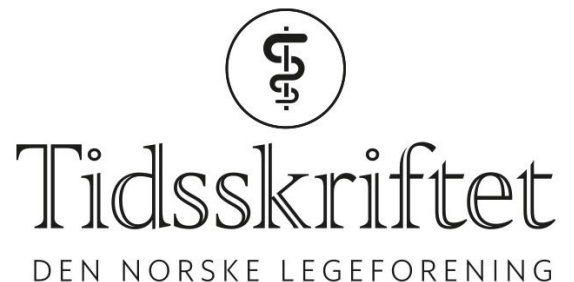

\title{
Legens nye status presens
}

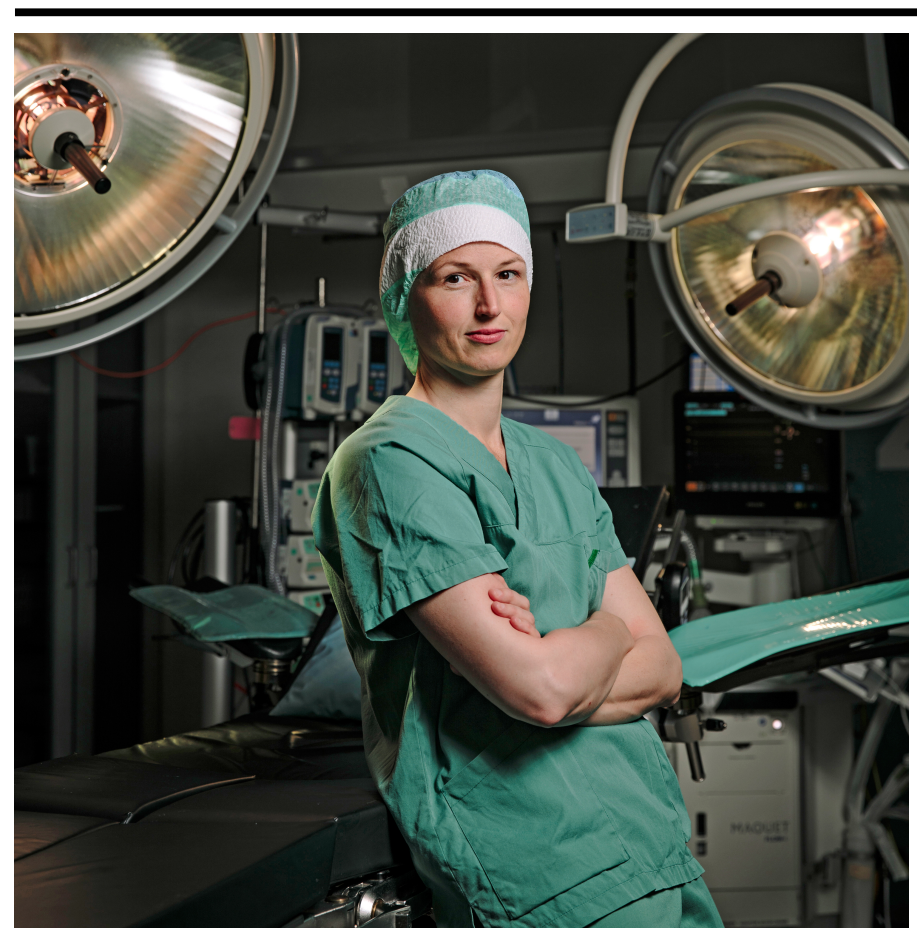

INTERVJU

CHRISTINA SVANSTR $\varnothing$ M

E-post: christina@svanstrom.no

Dagens leger har ikke den statusen legene hadde før. - Vi må innse at vi er arbeidstagere og jobbe for våre kollektive rettigheter, mener Trude Basso. 


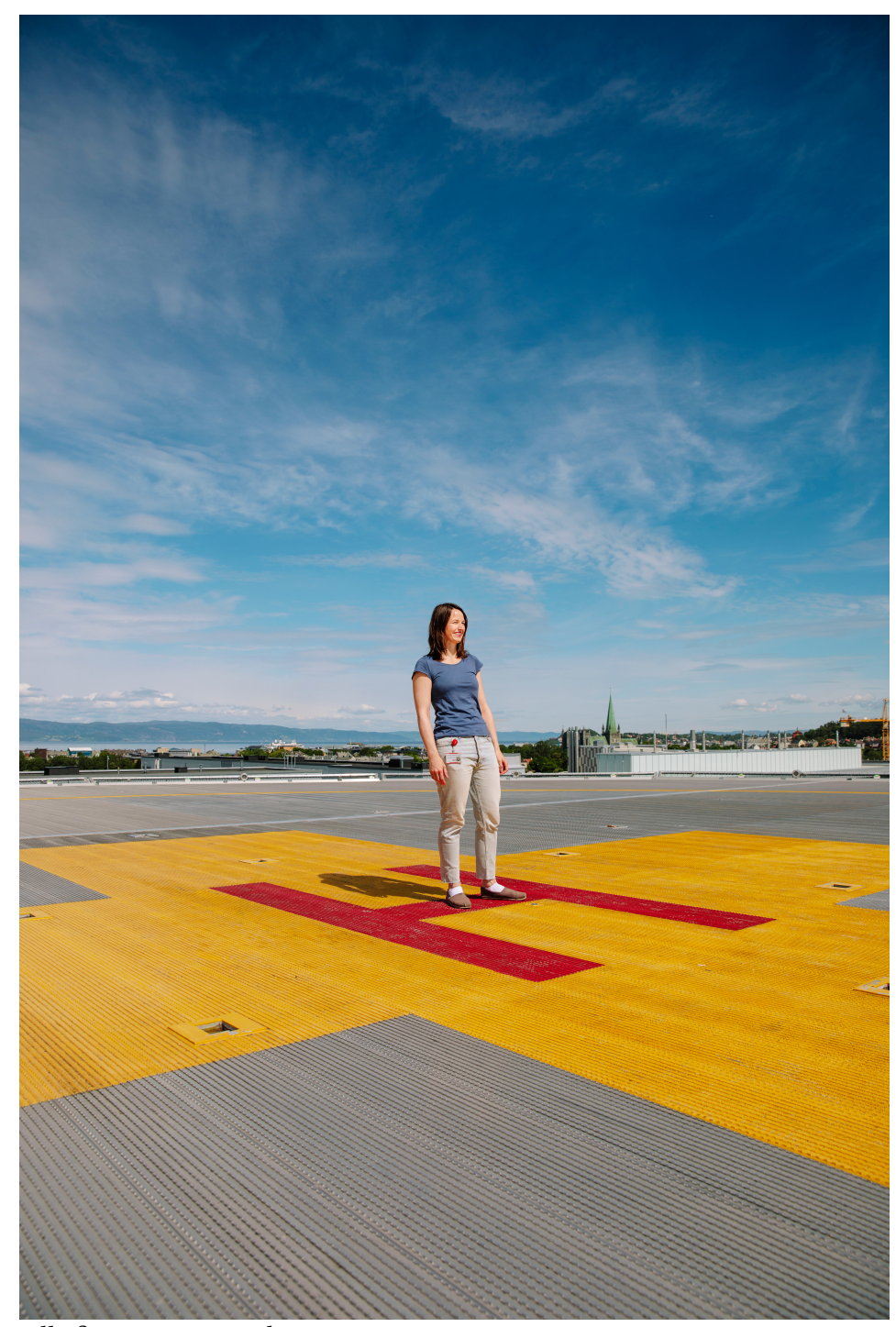

Alle foto: Marius Fiskum

Vi står på sykehusets tak og skuer utover Trondheim, en by som i dag bader i solskinn og sommerfølelse. Her oppe har vi den store oversikten. På helikopterplattformen lander mange av de akutt skadede som skal tas imot inne i sykehuset.

Allerede før pasienten kommer til sykehuset har mange hender og mennesker sett, snakket med, vurdert og hjulpet til. Det er en lang kjede av gode hjelpere som leder frem til kirurgen og videre derfra til ytterligere oppfølging hos andre.

- Er det ikke fantastisk? spør Trude Basso.

Basso er lege i spesialisering i ortopedisk kirurgi. Det siste året er hun blitt et navn i den offentlige sykehusdebatten. Livet på barrikadene har ikke bare vært enkelt. Men kirurgen på St. Olavs hospital ser ingen alternativer til å kjempe for det hun tror på.

- Hva har fått deg til å bli engasjert i den pågående sykehussaken?

- Jeg ser ikke noe annet valg. Hvis vi ønsker å bevare det norske helsevesenet som et gode for alle, må vi si ifra nå.

- Hva er det som driver deg?

- Flere ting, men først og fremst har jeg bestemt meg for at vi skal få tilbake retten til kollektive arbeidstidsavtaler. Jeg ser at enkelte deler av sykehusdriften skjer på grensen av det forsvarlige. Dette gjelder vaktbelastningen ved enkelte avdelinger og hastigheten behandlingen gjennomføres i, sier Basso.

Hun mener utdanning av spesialister og ivaretagelse av spesialistenes kompetanse taper terreng til fordel for såkalt effektiv drift. 
- Vi har absolutt et helsevesen vi kan være stolte av, men jeg tror vi står ved et veiskille. Akkurat nå er det veldig viktig å velge den rette veien, sier hun.

For Basso er det store spørsmålet hvordan vi skal bygge fremtidens Helse-Norge.

\section{Nå eller aldri}

- Det siste året har vært heftig, mildt sagt. Hva ledet deg inn i engasjementet rundt akkurat sykehusstreiken?

- Det har vært veldig artig, men jeg må innrømme at jeg av og til har vært sliten. Likevel klarer jeg ikke la være. Vi må få sikret arbeidsforholdene for legene. Hvis arbeidsgiver får «individualisere oss», slik at vi mister det å jobbe sammen som et kollektiv, er vi på helt feil kurs. Det er vi som er sykehuset, ikke mange enkeltstående jeg, sier Basso.

Hun snakker om den kollektive arbeidsmetoden. Hvordan vi sammen er sterkest - ikke hver alene med sitt. Om kompetanse som et kunnskapsfellesskap, ikke en individuell og kvantifiserbar ressurs.

- Hvis vi vanner ut kompetansemiljøet, som ved å utvide tidsrommet for hva som er normal driftsperiode, uten at dette gjenspeiles i flere ansatte innen alle disipliner, mister vi det kollektive miljøet som skaper rom for erfaring og læring: Vi taper gode arbeidsforhold, og vi taper den gode opplæringen av fremtidens leger, sier Basso.

Vi har beveget oss ned fra helikopterplattformen og har satt oss på plattingen utenfor en av de mange fine kafeene på St. Olavs. Det er sol og varmt, og vi har oppbrettede ermer og bukseben. Basso lener ryggen inntil treverket og sier det er godt med litt sol før nattevakten. Vi må huske å minne henne på at hun må spise før vaktstart, hvis ikke kan det gå virkelig skeis, sier hun.

«Det er mot i det. Hun vet at hun ikke bare får venner av å te seg på den måten. Hva får henne til å ville våge å være så tydelig, klar til å ta konsekvensene som vil komme?» sa en av dem jeg snakket med i forkant av intervjuet.

- Hvordan har det vært å stå i all oppmerksomheten?

- Å stikke hodet frem på den måten jeg har gjort det siste året, har vært nytt for meg. Men jeg at føler jeg snakker for veldig mange, og uten at jeg visste det selv, virker det som jeg klarer formidle det slik at mange kan stille seg bak, sier Basso.

- Har det vært en udelt positiv opplevelse?

- Jeg merker ingenting negativt på avdelingen, alt er som før på jobben. Den eneste forskjellen er at andre ansatte, pasienter og pårørende føler at de kjenner meg gjennom det jeg skriver - uten at jeg kjenner dem. På den måten blir jeg litt sårbar som kliniker. Et konkret eksempel ville være hvis en pasient eller en perifer kollega var misfornøyd med meg. Siden jeg er et kjent fjes, henger det mye lettere ved, sier Basso.

Det er det å ha forskjellige roller som føles nytt og merkelig. På den ene side å ha pasientansvar og være en kollega på sykehuset og på den annen side å være en offentlig person på debattsidene.

- Jeg blir på en måte redd for å skulle si eller gjøre noe feil, fordi det kan slå hardere tilbake. Men på avdelingen jeg jobber, er ikke det noe problem.

Engasjementet har vært tydelig og uten filter. Et eksempel er da direktør Stig Slørdahl i Helse Midt-Norge tidligere i år valgte å presentere sine visjoner frem mot 2030 på en effektiv heistur. Det tok ikke lang tid før Basso grep tak i temaene selv og presenterte sine egne tanker om pasienter, personale, teknologi og lagspill på en tilsvarende heistur under en nattevakt. Deretter la hun det hele uredigert ut på YouTube.

- Det var ganske klar tale, som du ofte fører. Får du noen reaksjoner?

- Det er noen hos oss i Yngre leger forening (Ylf) som mener vi ikke skal være for krasse eller brenne broer og ødelegge for fremtidig samarbeidsklima. Men jeg mener det er viktig å 
gjenkjenne og si ifra når jeg opplever det snakkes i floskler og vyer. Jeg er tilhenger av å være konkret og tydelig i kommunikasjonen.

Hun gjentar igjen og igjen det som betyr aller mest for henne: Et sterkt og offentlig norsk helsevesen. Og fremhever alle de forutsetningene som etter hennes mening er helt avgjørende for å beholde nettopp det.

På e-post sender hun meg den utførlige smørbrødlisten med poenger. Kort oppsummert trekker jeg ut det som kunne vært et utdrag av innholdsfortegnelsen i Bassos fremtidige litterære drømmeverk med tittelen Slik skulle helsevesenet vcert, sånn helt ideelt sett:

Gode og ryddige arbeidsforhold i sykehusene

Tilrettelegging for menn og kvinner som ønsker få barn

Gode nok rammer for god faglig fundert pasientbehandling

Helhetlig medisin, ikke etter brannslukningsprinsippet

God kultur for spesialistutdanning - og gode vilkår for forskning og undervisning

I en alder av 39 år og som lege i spesialisering kjenner hun selv på kroppen behovet for at det blir lagt til rette for at alle skal kunne lære best mulig og mest mulig. Hun mener for eksempel at et kirurgisk inngrep uten medvirkning fra en lege i spesialisering burde anses som halvveis bortkastet.

- I dag legges det mye vekt på effektivitet, innen både spesialistutdanningen og forskningsutdanningen. Av og til er det viktig å skynde seg langsomt for å la ting modnes. Vel anvendt tid kan også være effektiv! Det er ikke mye effektivt å utdanne en generasjon med papirspesialister, sier Basso.

\section{Prioriteringer}

Hittil har hun fullført en doktorgrad i medisin, fått tre barn, nesten fullført en spesialistutdanning som ortopedisk kirurg og tatt en prominent plass i den norske sykehusdebatten.

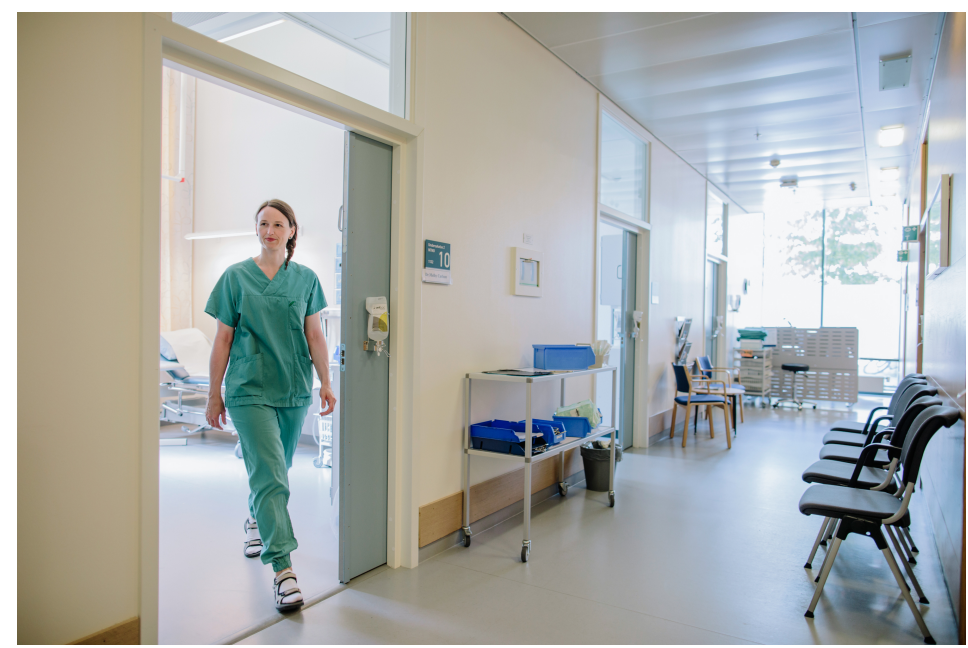

Etter endt turnustjeneste ved Orkdal sjukehus ønsket Basso ta fatt på doktorgraden. Det ledet henne frem til et uavhengig forskningsprosjekt om et nytt implantat for lårhalsbrudd, under ledelse av seksjonsoverlege Olav Foss på St. Olavs hospital.

- Det passet meg veldig bra - et konkret prosjekt for min konkrete hjerne. Målet var å finne ut om et nytt prinsipp for fiksering ville gi bedre lokale forhold for bruddtilheling enn de gamle implantatene.

Det som i utgangspunktet var en rent biomekanisk søken etter svar, åpnet for nysgjerrigheten etter å lære mer om de gamle pasientene som får hoftebrudd. Mer enn bare det isolerte studiet av ben, implantat og mekanikk ble Basso fengslet av spørsmål om mennesket som fortsetter i begge ender av bruddspalten. 
- Hvor mye nytte har vi av kun å se på rent biomekaniske markører uten i en større sammenheng? Og når skal vi innen forskningen lære oss å si at noe er godt nok og bruke ressursene på andre utfordringer? spør Basso.

- Tenker du at vi kan bli for snevre i hvordan vi bruker forskningsressursene våre?

- Alt vi gjør og dedikerer oss til, bør være nyttig for noe. Hvis noe utgjør en så liten forskjell at det ikke har noe å si for pasienten, skal pengene brukes der, da?

Hun er skeptisk til et forskningsklima der vi i det endeløse tester det ene mot det andre ved hjelp av etter hvert enorme registre. Basso mener dette kan gå på bekostning av grunnforskningen.

- Det er i grunnforskningen at de store fremskrittene kommer. Hvis du ikke får etablert de basale forståelsene, stopper det opp, sier Basso.

- Ikke alle forbedringer er til det bedre?

- Hvis vi skal trekke inn noe nytt i behandlingen, må også pasientene oppleve at det blir bedre, slik at det lønner seg mot den merkostnaden det faktisk har. Det holder ikke at det blir bedre kun fra et akademisk ståsted.

Å sette spørsmålstegn ved hvordan pasientene selv påvirker ressursfordelingen, er på mange måter tabu. For Basso er det en tydelig brannfakkel å skulle kritisere «pasientens helsevesen», og hun velger sine ord med omhu.

- Problemet er når det går mote i hva man prioriterer. Mitt spørsmål er hvor vi skal sette grensen for ytre påvirkning på faget. Hvis sterke pasientorganisasjoner alene eller gjennom politikere får dominere over fagpersoner i allokeringen av ressurser, har det gått for langt, mener Basso.

Hun nevner de svakeste gruppene - de multisyke, de gamle og de pleietrengende, de som ikke nødvendigvis kan passe inn i én representativ brukerorganisasjon.

- Det er ikke alle som har noen som kan rope for dem. Å se en pasient kun som del av store grupper er misvisende. Dermed er utrendy forskning kanskje den viktigste vi har, siden også de svakeste pasientene da kan bæres med i fremskrittet.

\section{Trude Basso}

- Født i 1978 i Trondheim

- Oppvokst på Otta, bosatt i Trondheim. Gift, tre barn

- Cand.med. Universitetet i Oslo 2007

- Ph.d. ved Norges teknisk-naturvitenskapelige universitet 2014

- Vikar som assistenlege ved Akuttpsykiatrisk avdeling, Aker sykehus, 2007-o8

- Turnustjeneste Orkdal sjukehus/Trondheim kommune, 2009-10

- Stipendiat ved Ortopedisk avdeling, St. Olavs hospital 2010-13

- Lege i spesialisering ved Ortopedisk avdeling, St. Olavs hospital fra 2010

- Førsteamanuensis II ved Norges teknisk-naturvitenskapelige universitet 2015-16

- Styremedlem i Faggruppe for osteoporose og beinhelse, Norsk ortopedisk forening, fra 2011

- Varaforetakstillitsvalgt ved St. Olavs hospital for Yngre legers forening (Ylf) 2016-17

- Redaktør for yngreleger.no 


\section{Formidleren}

- Vil vi ha gode offentlige sykehus, er det nå det må skje, sier Basso.

Hun peker på støtten hun har fått det siste året -ikke bare i Ylf, men også i Legeforeningen.

- Det er akkurat som om det har gått opp for mange flere at vi er blitt arbeidstagere - vi har ikke den maktposisjonen vi hadde tidligere. Det gjør at flere har vist seg fra en ny side i den senere tid.

Til høsten overtar Basso vervet som redaktør for nettsidene til Ylf. Christer Mjåset, leder i Ylf, sa følgende om å få henne som redaktør: «Hun har en etisk og medisinsk forståelse som overgår de fleste. Hun vet hva hun vil og kan begrunne det. Og hun kan akseptere et nei og gå videre. Derfor er hun lett å jobbe med.»

- Hva ønsker du å formidle i rollen som redaktør for yngreleger.no?

- Som redaktør vil jeg nok være farget av mine egne erfaringer. Vi yngre leger har en ganske alvorlig jobb med stort ansvar og høy arbeidsbelastning. Den dagen sykehusleger går på jobb med et sukk, har det offentlige helsevesenet tapt, sier hun.

- Jeg vil bruke redaktørjobben på å synliggjøre hva som skal til for at vi skal ha en best mulig offentlig helsetjeneste i dag og i fremtiden. Vi skal bare utdanne A-leger her i landet, og kvaliteten skal ikke lide på grunn av kortsiktig "profitt» i en oppkonstruert økonomi. Slitne av inntrykk og fulle av Bassos engasjement og ideer sitter vi på en benk utenfor ambulanseinngangen. Området er halvveis park, halvveis byggeplass.

Vi har beveget oss fra helikopterplattformen via kafé, forskningskorridorer, operasjonsstuer og poliklinikk til denne benken.

- Det viktigste å formidle er at vi må kjempe for retten til kollektive arbeidsavtaler, sier Basso, før hun legger fra seg det første tomme pizzapapiret og løfter opp det andre stykket. Klokken nærmer seg time to og maten må spises opp.

Dagen ender med klissete pizzabiter fra kiosken på hjørnet. Tiden løp fra oss, og Basso følte ikke for å spise salat i kantinen.

- Akkurat nå er det veldig viktig å velge riktig vei. Så spørs det om folket og de folkevalgte er enig med meg om hva som er målet. På det de folkevalgte sier, kan det jo virke sånn, men ser man på hva de gjør, er jeg ikke lenger så sikker.

Publisert: 4. oktober 2017. Tidsskr Nor Legeforen. DOI: 10.4045/tidsskr.17.0711

(C) Tidsskrift for Den norske legeforening 2020. Lastet ned fra tidsskriftet.no 